\author{
Journal of Markeing and Information Systems \\ (JMIS) \\ ISSN: \\ www.readersinsight.net/jmis
}

\title{
Value Relevance of Accounting Information: An Empirical Analysis of Banking Sector of Pakistan
}

\author{
Shahida Perveen \\ COMSATS University Islamabad, Abbottabad Campus
}

* Corresponding author:shahidaperveen_89@yahoo.com

\begin{abstract}
Accounting Information contained in financial statements is relevant \& reliable enough to present an indication of a business performance and financial condition to decision makers including investors. This study attempts to address the value relevance of accounting information in investor's decisions in Pakistani stock market. The relevance of accounting information is measured via correlation coefficient between average share price and cluster analysis is used to investigate the value relevance of large size firms and small size banks, further more incremental analysis and redundant variable test is also performed to check out the contribution of each variable in the model. Selective accounting information measures such as earning per share, equity, operational profit, size and age of firm, economic growth and non-traditional activities. Data set in this study consists of accounting information from published financial statements of commercial banks listed at Karachi Stock Exchange for a period of 6 years from 2007 to 2012. The result shows that there is a strong relationship between accounting information and average share price. The most important value relevant variables are EPS, firm size and operational profit. The investors consider these instruments for investment decisions. All these variables are significant and value relevant. Hence, accounting information is value relevant in Pakistani financial market.
\end{abstract}

Keywords: Value Relevance, Accounting Information, Average Share Price.

ARTICLE INFORMATION

Received: 15 December 2018

Revised: 25 January 2019

Accepted: 02 February 2019

DOI: 10.31580/jmis.v1i2.881

\section{INTRODUCTION}

Value relevance of accounting information is an operationalized form of the relevance and reliability criteria. Value relevance is one of the prime areas of research in accounting. It scrutinizes the relationship between share price and financial information in the form of variables. Term value relevance is often used to evaluate the accounting numbers. Accounting numbers are highly value relevant if they identify a high degree of association with market value of measures. Value relevance means that there is a statistical association between stock price, return and financial information. This study analyse the relevance of accounting information in investor's decisions in Pakistani stock market for the time period between 2007 2012. This section consists of background of the problem, literature review, objectives and organization of the study.

\section{Background of the Study}

Value relevance means that there is a statistical association between stock price, return and financial information. Relevance and reliability are the two main qualitative characteristics of financial accounting information. Relevance requires that the information should be user friendly and expected to affect their decisions. Reliability necessitates that the information should be truthful. The quality of accounting information is stiff to establish. According to the International Accounting Standards, relevance is one of the fit criteria through which quality can be assessed. The quality of accounting information is a standard on which users make correct economic decisions even though many studies suggest that investors make decisions based on the quality of reporting. Financial sector plays a vital role in the economy via capital allocation and contributes towards the economic growth. Banking sector is at the top in that sector. The reasons of accounting information are to present information of a business regarding its assets, liabilities, equity, revenue, income, expenses, profits and losses, and cash flows etc. It supports users forecast for future cash flows, estimate the timing and the degree of certainty of making cash flows and cash equivalents. Accounting information assists managers to evaluate the situation of the firm, whether operations are up to the standards or not; which field carries potential for success of the enterprise the strengths and weaknesses of the financial situation of enterprises; which requires alteration in progress to increase business value. Financial accounting field presents effective information to investors, so as to assist potential investors on funds assessment and making investment decisions. Several studies conducted in the field of banking sector to measure the value relevance of accounting information and documented mix evidence about value relevance for different stock exchanges.

Value relevance of accounting information are well documented in earlier studies, For example value relevance of accounting information (Alali and Foote, 2012; Mortinez-Sola et al., 2012; Kusnadi, 2011; Wu et al., 2010; Ehie and Olibe, 2010; Beasley et al., 2009; Habib Weil, 2008; Curry et al., 2008; Agusman, 2008; Chen et al., 2001; Graham and Frankenberger., 2000; Graham and King., 2000; King and Langli., 1998; Kallunki et al., 1998;).

Several investigations and researches pointed out the relationship between accounting information and stock price of the 
company is discussed as below. Alali and Foote (2012) examined the value relevance of accounting information in the Abu Dhabi Stock Exchange. Mortinez-Sola et al. (2012) investigated the effect of cash holding on firm value and they choose a sample of US industrial for the period of 2001-2007. Kusnadi (2011) analysed the relationships among firm-level corporate governance mechanisms and cash holdings; Wu et al. (2010) investigated the impact of accounting information for investments decisions. Ehie and Olibe (2010) \& Beasley et al. (2009) findings were same, Ehie and Olibe (2010) investigated the relationship between investment in research and development and market value among US firms for 18-year period having 26,500 firm-years. Habib Weil (2008) analysed the impact of the 1993 financial reporting regulatory reforms in New Zealand on the value-relevance of accounting information. Curry et al. (2008) empirically analysed whether equity market variables can provide accurate information and add value to accounting models that predict changes in bank holding company risk ratings over the 1988-2000 duration. Agusman (2008) measured the relation between accounting and capital market risk measures for the period of 1998-2003 using the sample of 46 listed Asian banks. Chen et al. (2001) examined the value relevance of accounting information in the Chinese stock market recognize accounting information based on Chinese GAAP to be value-relevant. Graham and Franken berger (2000) examined the asset value of advertising expenditures with the sample of 320 firms in 1994. Graham and King (2000) examined the relation among stock prices and accounting earnings and book values in six Asian countries: Indonesia, South Korea, Malaysia, the Philippines, Taiwan, and Thailand. King and Langli (1998) investigated accounting numbers and stock prices crosswise three countries: Germany, Norway, and the United Kingdom (UK). Kallunki et al. (1998) presented new verification on the relationship between various income-to-book and market-to-book equity ratios using Finnish data. Eccher et al. (1996) investigated the value relevance of fair value data disclosed under SFAS 107 by banks for 1992 and 1993. The literature concerning the value relevance of accounting information is comprehensive. Abiodun and Abumutair (2012), Deaconu (2010), Elisa (2013), Mohammadi et al. (2012), Nayeri et al. (2012), Preera (2010), and Vishnani (2008), found a positive relationship between accounting information and stock price.

Financial information includes the financial statements which are written record of financial situation of any business. They include balance sheet, income statements, and cash flow statements. They are the most essentials components of business information and source of communication about an entity to outside parties. According to the Accounting Standard Board, financial reporting not only includes the statements, but also includes the means of communicating financial information about an organization to external users. It is a broad concept which lay on financial statement, notes and necessary information needed by those who make economic decisions. Vishnani (2008) proved no relevance of accounting information for Indian stock market. Nayeri et al. (2012), documented a positive relationship for Tehran stock exchange. Mohammadi et al. (2012), concluded that investors did not use accounting information, while decision making as there was a lack of understanding about accounting information by the market participants. Khanagha in 2011 suggests that after the adoption of new approaches, the value relevance of accounting information has decreased. This paper contributes in the literature by using the financial information and impact of this information on investors' decision in Pakistani stock exchange. The results related to the value relevance of accounting information suggest that accounting information is value relevant in Pakistan and investors can rely on this information for their decision making.

\section{LITERATURE REVIEW}

The term value relevance is often used to evaluate the accounting numbers. An accounting number is a value relevant if it displays a high degree of association with market measures of value (French and Shipper, 1999), Collins et al. (1997). Several studies conducted on the value relevance of accounting information internationally result in mix evidence.

Choi 2007; Barth et al. 1996, Anwar wt al. 2006, Eccher et al. 1996, Nelson 1996, Barth 1994, investigated the relationship between accounting information and companies value. Nayeri et al. (2012) conducted a study of value relevance of accounting information in Tehran Stock Exchange. For this purpose they collected data of 106 listed firms on TSE for the period of 2001 to 2007. They use Ohlson model (the model of book value and market value) and regression analysis to test the hypothesis. They used profitability, size, earning and growth as independent variable with value relevance of accounting information. They concluded that investors give more importance to profitable sustainable firms in purchasing shares and used this information for decision making. They also found that investors also consider firm size in their decision making and there is more value relevance for small size firms. While a negative relationship was found between firm's growth and value relevance.

Perera and Thrikawala (2010) studied the listed firms on Colombia stock exchange to find out the relevance of accounting information on the decisions of investors. By using the sample of commercials banks listed on CSE for the period of 2006 to 2009. They applied correlation and regression analysis to study the phenomena. For value they used market price per share. They used accounting information in the form of earning per share, return on equity, earning yield, and found that investors consider all accounting information presented in financial statements for their investment decisions and EPS, ROE, and EY have a value relevance. Mohammadi et al. (2012) investigated the relationship between value of the companies and accounting information. They collected data of 194 active companies listed on Tehran Stock Exchange for the period of 2007 to 2009. They considered the value of the company as dependent variable and other financial statements as an independent variable. They used systematic random sampling method and concluded that there was no relationship between the value of the company and accounting information. They also concluded that investors did not use accounting information while decision making. Other studies in this field included the studies of Lourenço \& Curto (2008), Hung \& Subramanyan (2007), Bartov, Goldberg \& Kim (2005), Lopes (2001) and Hung (2001). Lourenço and Curto (2008). Abiodun (2012) examined the relevancy of accounting information in Nigerian firms for the period of 1999 to 2009. For this purpose he collected data of 40 firms listed at NSE. He employed descriptive statistics technique and multiple regression analysis. This major focus was on measuring the earning and book value information on share price. Earning means current information related to profitability presented in income statement, while book value is historical value presented in balance sheet. The finding of the research shows that earning is more relevant in the NSE as compared to book value. The reason is that investors give much attention to current information for their decision making.

Deaconu (2010) analysed the value relevance of tangible assets and its variation depending on industry, size of the firm and age of devalue amounts. Their conclusions are based on the relationship with studies on developed markets. Salisu (2009) empirically investigated the value relevance of accounting information which was reported by new economy firms in Nigeria and also investigated the influence of this information on share price. He examined the value relevance of accounting information by using Ohelson model and collected data form Nigerian stock exchange for the period from 2005 to 2008 which included 18 firms relative to share price, market value, and earnings per share. The result obtained shows that there is a relevance of new listed economy firms and also shows that investors consider other information while making investment decisions in new economy firms. His results also indicate that TMT firms have major assets in intangible values which were not reported in financial statements, for the higher value relevancy it should be included in financial statements. Hadi (2004) investigated the importance of accounting information in stock exchange market. He use the sample of all the commercial Banks listed under KSE for the period from 1997 to 1999 by using accounting ratios as independent variable and market value 
as a dependent variable. The results show that accounting ratios such as ROTA. Earning, NIM, BURDEN and Yield are affecting stock prices in Kuwaiti stock exchange and investors are considering these ratios for investment decisions. Results related to loan loss was insignificant as no association found for the ratio which suggest that investors are not considering loan loss ratios for decision making.

Salisu (2009) investigated the value relevance of accounting information empirically which was reported by new economy firms in Nigeria and also investigated the influence of this information on share price. He examined the value relevance of accounting information by using Ohelson model and collected data form Nigerian stock exchange for the period from 2005 to 2008 which includes 18 new firms relative to share price, market value, and earning per share. The result obtained shows that there was a slight relevance of new listed economy firms which also shows that investors consider other information while making investment decisions in new economy firms. His results also indicate that Telecommunication media and technology firms have major assets in intangible values which were not reported in financial statements, for the higher value relevancy it should be included in financial statements.

Chen (2008) examined the sentiment over the accounting information. The paper focused on the uniqueness of various new ways of earning and investors expectations of cash flows and risks. As sentiment play vital role in decision making with the help of its components in the valuation model i.e. positive cash flow and negative cash flow, and the individual \& combined effects which determine the investors' responses. The finding of this study reveals that outcomes of sentiment over the risk identify control on decisions because lesser sentiment over the accounting information has no place for future investment decisions. This study further suggests for future researches that this sentiment and investors decisions relation can be tested on the different sectors and markets. Ball and brown 1968, Vishnani, S., Shah B.K., 2008, Donton A., 2000, Dung N.V., 2010, Hadi M.M., 2004, Oyerinde D.T., 2009, also measure the value relevance of accounting information. Abu Mutair and Alnairab (2012), conducted the importance of accounting information in Palestine stock exchange by the investors and investor awareness regarding accounting information, while making investment decisions. They used descriptive analytical method and collected information by interview and questionnaire analysis. They concluded that investors in PEX used the accounting information in decision making by analysing the importance of accounting information. They concluded that accounting information reduces the risk and also provides the least cost source of getting firms' financial information and accounting information is enough to make investment decisions. Their study also suggested that investors should be fully aware of accounting information; they must improve their knowledge regarding accounting policies, procedures and their usage. Elisa et al. (2013), investigated the impact of value relevance of accounting information on share prices in Sweden after the change in standards in 2005. For this purpose they had chosen the sample of listed firms at Nasdaq stock exchange and divided these firms into further categories i-e Large, mid and small cap and they mainly focused on large cap segment for the period from 2007 to 2010. By using Ohlson model they concluded that the value relevance from balance sheet has improved and increased as well after the change in standards, while the value relevance of income statement has decreased in its importance and accounting information is value relevant in Swedish market. Ghayoumi et al. (2011), examined the significance of accounting information by gathering data from Tehran stock exchange for the time span from 1999-2006. In this study they used earnings per share and annual change in earning and book value. They used return and price models to measure the significance of accounting information of Tehran stock exchange. The study found that there exists a significance relation of accounting information among the investors.

\section{RESEARCH METHODOLOGY}

The objective of this study is to test the relevance of accounting information in Pakistani Stock Market. The study is purely based on secondary data which is collected from the annual reports of the commercial banks of Pakistan and from business recorder, for the period from 2007-2012. The data on variables, equity, operational profit, firm size, EPS, and age is collected from the annual reports of the banks, while data for average share price is collected from business recorder. To test the hypothesis for this study we used regression analysis followed by descriptive statistics, correlation analysis, incremental regression and redundant variable test. study:

Based on above literature the following are the hypothesis of the

The main hypothesis of the study is that there is a strong relationship between accounting information and value relevance. The sub hypotheses are:

H1. Higher book value of equity, improves the stock price in Pakistan.

H2. Higher operational profit, improves the stock price in Pakistan.

H3. Higher EPS, higher will be the stock price in Pakistan.

H4. The larger firms present the highest value relevance in Pakistan.

\section{REGRESSION MODEL}

The model used in this study is as follow:

$\mathrm{Yit}=\alpha+\beta 1 \mathrm{tX} 1 \mathrm{t}+\beta 2 \mathrm{tX} 2 \mathrm{t}+\beta 3 \mathrm{tX} 3 \mathrm{t}+\beta 4 \mathrm{tX} 4 \mathrm{t}+\beta 5 \mathrm{tX} 5 \mathrm{t}+\beta 6 \mathrm{tX} 6 \mathrm{t}+$ $\beta 7 \mathrm{tX} 7 \mathrm{t}+\mu \mathrm{t}$ (Deaconu 2010)

Where,

$\mathrm{Y}=$ Dependent Variable (ASP),

$\alpha=$ Intercept,

$\beta 1 \mathrm{t}=$ Slope of variables;

$\mathrm{Xt}=$ Independent Variables/Control Variables (Equity, OP, EPS, FS, Age, EG and NTA)

$\mathrm{T}=$ Periods

$\mu \mathrm{t}=$ Error term

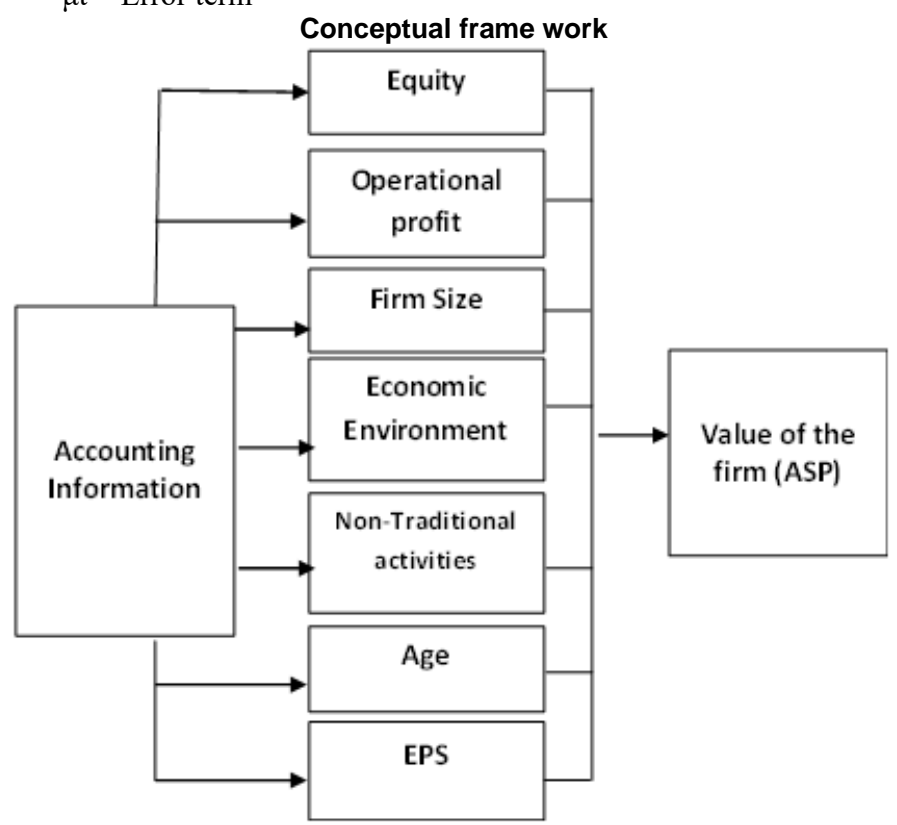

Fig 1.

\section{CONSTRUCTION OF THE VARIABLES}

On the basis of the hypothesis, we have developed and operationalized our variables. The variables included in the study are dependent variable, independent variables and control variables.

The first variable in used in this study is ASP (average share price). This variable shows the delegate compute of a range of prices.

Following are the independent variables of the study:

Equity is used as a positive variable in the literature (book value of shareholder's equity). It is calculated by adding share capital and retained earnings less treasury shares. Shareholders' equity 
symbolizes the amount by which a company is financed through common and preferred shares. This variable is used by Hadi (2004).

Third variable is Operational Profit which is Net income before tax, It is the distinction between operating revenues and operating expenses. If a firm does not have non-operating income, then operating income is sometimes utilized as a synonym for EBIT and operating profit. This variable is used by Deaconu (2010).

Fourth independent variable is Age of the firm since incorporation, Shumway (2001), argues that the economically most consequential measure of age is the number of years since listing. That event is a defining moment in a company's life.

An earnings per share is our fifth variable in the study. Earnings after tax /Outstanding shares. The revenue earned by a company later than meeting cost of production, then interest, depreciation and tax belongs to the equity shareholders. This variable is used by Hadi (2004). EPS measures the profitability of the company.

Firm Size is used as independent variable which is Log of total assets. The revenue after meeting cost of production, then interest, depreciation and tax belongs to the equity shareholders. This earnings divided by the number of outstanding equity shares is referred to as EPS. EPS measures the profitability of the company.

Control variable such as Economics Environment \%age change in GDP,and non-traditional activities are also used to analyse the value relevance of accounting information. Guenther and Young (2000) declared when the economy is expanding may exceed supply and hence boosting corporate earnings. Generally in a booming economic environment firms are more likely to hire additional labour to satisfy increased demand (Barron et al. 1989) thus spurring further growth. Non-traditional activities measured by Investments to Assets Ratio. Non traditional activity is measured by non lending activities, for example, investment to assets ratio (Rogers 1998).

\section{RESULTS AND DISCUSSION}

\section{Descriptive Statistics}

The descriptive statistics are calculated for analysing the basic features of variables. Descriptive statistic on operational profit, equity, earning per share, firm size, age, economic growth, nontraditional activities, are presented below:

Table 1 - Descriptive Statistic

\begin{tabular}{lrrrrr}
\hline Variables & $\mathbf{N}$ & Minimum & Maximum & Mean & S.D \\
\hline ASP & 116 & 1.160 & 399.950 & 34.550 & 56.513 \\
Equity & 119 & 88.802 & 238587.315 & 27604.367 & 4.119 \\
OP & 120 & -45250.237 & 34891.207 & 4283.676 & 1.030 \\
EPS & 118 & -5.490 & 26.170 & 3.636 & 6.428 \\
FZ & 120 & 926.699 & 960210.415 & 248195.4 & 2.191 \\
Age & 120 & 1.000 & 71.000 & 26.100 & 21.237 \\
EG & 120 & 1.700 & 6.800 & 3.635 & 1.532 \\
NTA & 119 & 0.002 & 19.65 & 3.66 & 5.197 \\
\hline
\end{tabular}

This table shows the descriptive statistics of the variables used in the study. The total observations for the descriptive statistics are 113. Data reveals some useful information. It is found that the mean value of average market price of the share among the sample firm is 34.5 rupees with the maximum value of 399 rupees. The average operational profit of the firm is 4283.676 . Average equity was found to be 27604.367 , this means that among the group of selected firms the average value of equity is 27604.367 . Descriptive statistics also revealed that the sample firms had an average of 3.63 rupees per share of earning. Firm size (FS) has a average value of. 248195.4 This means that $\log$ of total assets of the sample firms is 248195.4 .

\section{Correlation Analysis}

This section explains the correlation of independent variables with average share price. The Diagonal cells having value 1 represent the correlation between variables and themselves.

\begin{tabular}{|c|c|c|c|c|c|c|c|c|}
\hline & ASP & OP & EQUITY & FS & AGE & NTA & EG & EPS \\
\hline ASP & 1.000 & $.608^{* *}$ & .173 & $.480^{* *}$ & $.305^{\star *}$ & .121 & $.277^{* *}$ & $.857^{* *}$ \\
\hline OP & & 1.000 & .011 & $.397^{* *}$ & $.421^{* *}$ & $.274^{* *}$ & .012 & $.786^{* *}$ \\
\hline EQUITY & & & 1.000 & $.317^{* *}$ & $.265^{\star}$ & .171 & -.134 & $.226^{*}$ \\
\hline FS & & & & 1.000 & $.480^{\star *}$ & -.186 & -.082 & $.584^{\pi x}$ \\
\hline AGE & & & & & 1.000 & $.045^{\star *}$ & -.061 & $.395^{\star \star}$ \\
\hline NTA & & & & & & 1.000 & -.063 & $.204^{*}$ \\
\hline$E G$ & & & & & & & 1.000 & .045 \\
\hline EPS & & & & & & & & 1.000 \\
\hline
\end{tabular}

**. Correlation is significant at the 0.01 level (2-tailed).

*. Correlation is significant at the 0.05 level (2-tailed).

Correlation of ASP with OP is .607 which means that there is a strong positive correlation between variables meaning when ASP increases the value of OP also increases by 60 percent. However, Correlation matrix shows that there is a weak correlation between ASP and equity (.173). The correlation between ASP and FS is positive and the strength of the relation is (.480). It is depicted in the correlation matrix that there is a strong positive correlation among ASP and EPS. It is portrayed that all control variables have a positive relationship with dependent variable ASP, but Age has a moderate correlation, NTA and EG has a weak correlation. This finding is consistent with the findings of Nayeri el al. (2012), in which they concluded that Firm size has a positive impact on share price. Their results show that investor gives more importance to the firm size while making investment decisions. Further the above results are also consistent with the findings of Parera and Tarikawala (2010), Mohammadi et al. (2012), and Abu Mutair (2012), in which the Firm Size, Earning per Share and Operational Profit were Value Relevant and had an impact on investor decisions. The Age of the firm is found to have a positive correlation with average share price.

\section{CORRELATION ANALYSIS OF CLUSTERS}

The correlation analysis of clusters, which consist of two groups of large size and small size based on market capitalization, shows some imperative results. The result of large size presents that operational profit, earning per share has a strong positive correlation with average share price that is $56 \%$ and $84 \%$, while firm size, age, NTA, and EG has a moderate correlation with dependent variable. Only equity shows no correlation with Average share price.

On the other hand the results of small size shows that only earning growth (EG) has a strong correlation with average share price, all the other variable has a week and somehow moderate correlation with dependent variable.

The overall results of both large size and small size show that larger firms present higher value relevance and had an impact on investor's decisions, which leads to the acceptance of H4.

Table 3 - Correlation analysis of Clusters

\begin{tabular}{lllllllll} 
& ASP & OP & EQ & FS & AGE & NTA & EG & EPS \\
\hline $\begin{array}{l}\text { Large } \\
\text { size }\end{array}$ & 1.000 & 0.56 & 0.00 & 0.37 & 0.18 & 0.14 & 0.38 & 0.84 \\
$\begin{array}{l}\text { Small } \\
\text { size }\end{array}$ & 1.000 & 0.38 & 0.31 & 0.29 & 0.56 & -0.0 & 0.50 & 0.63 \\
\hline Source & Authen
\end{tabular}

Source: Author estimates

\section{Regression Analysis}

The regression analysis in the model is based on dependent variable, independent variable and control variable. As it is discussed before that the average share price is the dependent variable while operational profit, earning per share, firm size, age, and equity are the independent variables. Economic growth and non traditional activities are the control variables. Multiple regression analysis is performed to test all hypotheses for the model of the study.

To test our hypothesis H1, we use ordinary least square regression. Equity is not significant with dependent variable i.e. average stock price and also have negative coefficient value (-4.425) which shows negative effect of equity on average stock price. 


\begin{tabular}{llcc}
\hline \multicolumn{3}{l}{ Table 4 - Regression Results } & \\
\hline S.N & VARIABLES & COEFFICIENT & PROBABILITY \\
\hline 1 & C & 17.02555 & 0.5295 \\
2 & (LOG) EQUITY & -0.425751 & 0.7667 \\
3 & (LOG) OP & 7.101194 & 0.0025 \\
4 & EPS & 8.923540 & 0.0000 \\
5 & (LOG) FS & 1.722760 & 0.0576 \\
6 & AGE & 0.308619 & 0.6209 \\
7 & EG & 3.463586 & 0.0403 \\
8 & NTA & 0.843901 & 0.3840 \\
9 & AR(1) & 0.249398 & 0.0021 \\
& R-squared & 0.849190 & \\
& Adjusted R-squared & 0.828389 & \\
& F-statistic & 45.00659 & \\
& Durbin-Watson stat & 1.670555 & \\
\hline
\end{tabular}

The reason is that financial service firms differ from non financial firms on debt and equity basis. In financial service firms debt (deposits) is considered as raw material, which can be sold at higher price. Financial service firms traditionally tend to use more debt in funding their business in order to have more predictable earnings and because of regulatory frame work (Damodaran, 2009), so we found negative relationship of higher equity and rejecting our first hypothesis.

The Coefficient value for $(\log )$ OP is moderately higher (7.101), as contrast to other variables. To determine the statistically significant unique input of each variable to the equation, Operational profit is significant at 0.000 and has a positive effect (7.101), operational profit gives the idea of general health of a company. If company is facing higher operating income then it is making more money for shareholders leading towards upward movement in share prices. This result accepted our hypothesis $\mathrm{H} 2$.

Our third hypothesis H3 is supported. The earnings divided by the number of outstanding equity shares is referred to as EPS. This variable is used by Hadi (2004). EPS measures the profitability of the company. The EPS is significance $(0.000)$ and have positive effect (8.92) on stock price. Earnings per share strongly affect the average stock price. This accepts our H3. Result shows that when earning per share (EPS) increases it increases the stock price of the company. Parear and Thrikwala (2012), and Salisu (2009) also reported a positive association between Earning per Share and Average Share Price

Age has a positive effect on asp but is not significant with asp. Percentage change in GDP (EG) is significant and has a positive relationship; this shows that when there is an increase in the GDP, it improves the share price of the company. Non-traditional activity which is our control variable is not significant but has positive effect on dependent variable.

To test the effect of size on the stock price, we look for the log of firm size. The revenue earned by a company after meeting cost of production, then interest, depreciation and tax belongs to the equity shareholders. Log (FS) is significance (0.05) with the Average share price and has a positive effect (1.722) on the ASP. It shows that firm size has an effect on the share price of the firm. Larger firms present high value of tangible assets, the greatest financial force to generate future economic benefits.

\section{Cluster Analysis}

To test our H4 we use cluster analysis. We use 2 cluster analyses for this hypothesis, one for large firms and other for small firms.

Table 5 - Cluster analysis of large size Banks

\begin{tabular}{lcc}
\multicolumn{2}{l}{ Table 5 - Cluster analysis of large size Banks } & \\
\hline Variables & Coefficient & Probability \\
\hline C & 31.02327 & 0.8078 \\
LOG(EQUITY) & 1.947011 & 0.4810 \\
LOG(OP) & 9.61121 & 0.0238 \\
EPS & 10.09379 & 0.0000 \\
LOG(FS) & 4.738464 & 0.4468 \\
AGE & 0.134565 & 0.2900 \\
EG & 20.36147 & 0.0000 \\
NTA & 0.036592 & 0.8176 \\
\hline
\end{tabular}

$\begin{array}{rc}\text { R-squared } & 0.830726 \\ \text { Adjusted R-squared } & 0.807955 \\ \text { Durbin-Watson stat } & 2.313534 \\ \text { F-statistic } & 29.26535\end{array}$

In Large size the Equity, EPS, Firm Size, EG and OP has a positive effect, but Equity, Firm Size, Age and NTA are not significant ,However, EPS is significant (0.000), OP (0.02) and EG (0.00) respectively.

\begin{tabular}{|c|c|c|}
\hline Variables & Coefficient & Probability \\
\hline C & 126.0274 & 0.2266 \\
\hline LOG(EQUITY) & -4.59053 & 0.2603 \\
\hline LOG(OP) & 5.269970 & 0.0691 \\
\hline EPS & 14.12637 & 0.000 \\
\hline $\mathrm{LOG}(\mathrm{FS})$ & 9.309514 & 0.1841 \\
\hline AGE & 0.163954 & 0.6851 \\
\hline$E G$ & 2.125740 & 0.1632 \\
\hline NTA & 0.030986 & 0.9075 \\
\hline R-squared & 0.781544 & \\
\hline Adjusted R-sq & 0.763986 & \\
\hline Durbin-Watson s & 1.854935 & \\
\hline F-statistic & 22.030783 & \\
\hline
\end{tabular}

Source: Author Estimates

\section{CLUSTER ANALYSIS OF SMALL SIZE}

Cluster analysis of small size is a bit different; Equity has a negative effect on share price and is significant. OP is significant and has a positive effect on share price but not significant. The effect of the earning per share is significant and also has positive effect on share price. With the case of firm size, it is significant and has negative effect on share price. The cluster analysis of small firm size is showing that small firms have not highest value relevance. Our result shows that the small firms have no impact on share price.

\section{Incremental analysis}

The test for incremental regression analysis was performed to confirm the importance of independent variables in affecting the average share price. We have used five models for this purpose and excluded each variable from the main model one by one

Table 7 - Incremental analysis

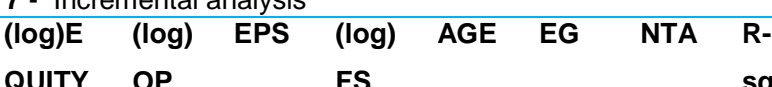

Qre

$\begin{array}{lllllllll}\text { Mo } & * \star \star \star \star * & 12.4 & 8.92 & 12.0 & 0.03 & 9.18 & 0.36 & 0.84 \\ \text { del } & & 08 & 473 & 7214 & 8234 & 2556 & 3792 & 9189 \\ 1 & & (0.00 & (0.00 & (0.03 & (0.60 & (0.00 & (0.31 & \\ & & 28 & 00 & 96 & 42) & 01) & 14) & \\ \text { Mo } & 0.0232 & * * * * & 7.94 & 0.43 & - & 8.51 & - & 0.79 \\ \text { del } & 17 & * & 8477 & 3072 & 0.05 & 4309 & 0.03 & 4823 \\ 2 & (0.990 & & (0.00 & (0.88 & 7298 & (0.00 & 7834 & \\ & 9) & & 00) & 17) & (0.55 & 00) & (0.64 & \\ & & & & & 58) & & 99) & \\ \text { Mo } & - & 12.4 & * \star * * * & 18.3 & 0.05 & 9.61 & 9.78 & 0.44 \\ \text { del } & 3.5874 & 1210 & * & 6812 & 1084 & 7594 & 5652 & 4745 \\ 3 & 62 & (0.07 & & (0.14 & (0.79 & (0.02 & (0.45 & \\ & (0.426 & 65) & & 50) & 99) & 28) & 21) & \end{array}$

4)

Mo $\quad 1.4129 \quad 6.70 \quad 8.96 \quad * \star * \star * \quad 0.03 \quad 7.55$ 


\begin{tabular}{lllllllll}
\hline del & 03 & 6413 & 6017 & $*$ & 7854 & 8726 & 0.30 & 9286 \\
4 & $(0.465$ & $(0.02$ & $(0.00$ & & $(0.63$ & $(0.00$ & 4390 & \\
& $5)$ & $45)$ & $00)$ & & $55)$ & $05)$ & $(0.07$ & \\
& & & & & & & $71)$ & \\
Mo & 0.7534 & 6.69 & - & 8.97 & 0.03 & 8.48 & $* * * *$ & 0.84 \\
del & 05 & 8777 & 9.83 & 8363 & 6763 & 9418 & $*$ & 6779 \\
5 & $(0.683$ & $(0.01$ & 1012 & $(0.00$ & $(0.63$ & $(0.00$ & & \\
& $6)$ & $38)$ & $(0.00$ & $00)$ & $58)$ & $01)$ & & \\
& & & $21)$ & & & & & \\
\end{tabular}

Source: Author estimates

When we remove the log of equity ((log equity) from the model it improves the goodness of fit (r-square) that is from $82 \%$ to $84 \%$ which shows that equity has negative effect on the model. This finding shows that equity does not have any contribution in the selection or does not have any valuable information which is useful for the investors in their decision making. Log of operational profit has a positive effect on the model; with its removal from the model, it decreases the R-square value from $82 \%$ to $79 \%$ which show that it has a positive effect on the model i.e. it changes the model $3 \%$, meaning that it has some information which can affect the decision of the investors, but it is not valuable. Earnings per share is the most significant variable in the model and also the most effective, $38 \%$ change has been made by earning per share, which shows that it is the most important variable for the model, meaning that earning per share gives the most important and valuable information to the investors. When we replace the EPS in the model it becomes normal to its original position.

\section{Redundant Variable Analysis}

Table 8 - Redundant Variable Test

\begin{tabular}{llrrrr}
\hline Sr & Variables & $\begin{array}{r}\text { Probabi } \\
\text { lity }\end{array}$ & $\begin{array}{r}\text { R- } \\
\text { squared }\end{array}$ & $\begin{array}{r}\text { Adjuste R- } \\
\text { squared }\end{array}$ & $\begin{array}{r}\text { Likelihoo } \\
\text { d ratio }\end{array}$ \\
\hline 1 & Log & 0.98 & 0.84 & 0.83 & 0.000 \\
& (EQUITY) & & & & \\
2 & AGE & 0.62 & 0.84 & 0.83 & 0.285 \\
3 & NTA & 0.34 & 0.84 & 0.83 & 1.03 \\
4 & EPS & 0.000 & 0.44 & 0.37 & 87.34 \\
5 & OP & 0.030 & 0.83 & 0.82 & 0.45 \\
6 & EG & 0.0000 & 0.80 & 0.77 & 17.92 \\
\hline
\end{tabular}

First redundant variable is $\log$ of equity. The redundant variable has no impact in the original model. Its F-statistic is 47.45 with a probability of 0.00 while applying redundant variable test for $\log$ of equity, all the other variables are significant and there is also no change in adjusted R-squared. The adjusted R-squared in the original model is $84 \%$ which is sum of redundant variable in log of equity. Then this test is applied on age that also shows that there is no significant impact of age in the original model. F-statistic for redundant variable of age is 47.22 with a probability of 0.000 which shows that this variable is least important in terms of value relevance and is highly insignificant variable. No change is adjusted R2 shows the insignificant impact of this variable on original model. R-squared is 0.84 . Our next redundant variable is NTA. The F-statistic 55.01 and the probability 0.00 shows that this variable is also insignificant and is of least important and contributing nothing to adjusted R-squared. EPS is the most important variable in this model. It shows most significant results. In original model the R-squared value is $84 \%$ while excluding the variable of EPS it becomes $44 \%$. It means that $52 \%$ change has been made by EPS which shows that it is the most important variable for the model.

\section{REDUNDANT VARIABLE TEST OF CLUSTERS}

The large size cluster redundant variable test shows EPS is more important variable in the model affecting R-Square from $74 \%$ to $38 \%$.
Rest of the variables are having equal weightage in the model having no effect on R-Square.

Table 9 - Redundant variable test of large size

\begin{tabular}{lcc} 
Variable & Probability & R-Square \\
\hline Equity & 0.802285 & 0.747750 \\
Operational Profit & 0.083844 & 0.732704 \\
EPS & 0.000000 & 0.383753 \\
Firm Size & 0.482155 & 0.745587 \\
Age & 0.739507 & 0.747511 \\
Economic Growth & 0.000037 & 0.748063 \\
Non traditional activities & 0.345087 & 0.818111
\end{tabular}

The redundant variable test for small firms shows comparatively low R-Square values for large size firms. All the variables have the same effect on the model. Among all variables EPS is also affecting $\mathrm{R}$-Square more than other variables.

Table 10 - Redundant variable test of small size

\begin{tabular}{lcc}
\hline Variable & Prob & R-Square \\
\hline Equity & & \\
Op & 0.102414 & 0.561393 \\
Eps & 0.552199 & 0.580663 \\
FS & 0.000093 & 0.439684 \\
Age & 0.060793 & 0.554111 \\
Eg & 0.938896 & 0.583483 \\
Nta & 0.000300 & 0.463216 \\
\hline
\end{tabular}

Table 11 - Two SLS results

\begin{tabular}{|c|c|c|}
\hline Variable & Coefficient & Prob. \\
\hline $\begin{array}{l}\text { C } \\
\text { LOG(EQUITY) } \\
\text { LOG(OP) } \\
\text { LOG(EPS) } \\
\text { LOG(FS) } \\
\text { LOG(AGE) } \\
\text { LOG(EG) } \\
\text { LOG(NTA) }\end{array}$ & $\begin{array}{c}95.2157 \\
-2.540016 \\
5.630937 \\
9.109476 \\
5.380960 \\
0.001627 \\
11.53456 \\
-0.051297 \\
\end{array}$ & $\begin{array}{l}0.2254 \\
0.3581 \\
0.1161 \\
0.0000 \\
0.2311 \\
0.9886 \\
0.0000 \\
0.6790\end{array}$ \\
\hline $\begin{array}{r}\text { R-squared } \\
\text { Adjusted R-squared } \\
\text { F-statistic } \\
\text { Prob(F-statistic) } \\
\text { Durbin-Watson stat }\end{array}$ & $\begin{array}{l}0.807946 \\
0.790486 \\
46.27542 \\
0.000000 \\
2.289966 \\
\end{array}$ & \\
\hline
\end{tabular}

In case of efficiency, R-square of the model for dependent variable (average share price) is 0.80 .The result explains that $80 \%$ variation is explained by the explanatory variables of the model and only $20 \%$ variation remains unexplained by independent variables. Two-stage least-squares regression uses influential variables that are uncorrelated with the error terms to calculate approximated values of the problematic predictors (the first stage), and then uses those calculated values to estimate a linear regression model of the dependent variable (the second stage). The results of two-stage leastsquares show that the Adjusted R-squared is $79 \%$ and all the variables other than EPS and EG are insignificant and shows negative relationship with share price. The only significant variable is EPS which is significant at $9 \%$ and has positive relationship with share price.

\section{Generalized Method of Moments}

Generalized Method of Moments (GMM) presents a computationally suitable method for calculating the parameters of statistical models based on the information in population moment conditions. The GMM approach is suited to deal with the important dynamic effects and accounts for endogeneity in the explanatory variables.

The result of GMM shows that adjusted R-squared is $62 \%$ and equity, age, operational profit and economic growth is insignificant. 
The finding shows that EPS, NTA and firm size are significant and shows positive relationship with dependant variable, i.e. Share price.

Table 12 - Generalized Method of Moments

\begin{tabular}{|c|c|c|c|}
\hline Variable & & Coefficient & Prob. \\
\hline $\begin{array}{l}\text { C } \\
\text { EQUITY } \\
\text { OP } \\
\text { EPS } \\
\text { FS } \\
\text { EG } \\
\text { AGE } \\
\text { NTA }\end{array}$ & & $\begin{array}{c}55.11345 \\
-3.5107 \\
2.2007 \\
4.569089 \\
7.5008 \\
-2.358189 \\
-0.023189 \\
2.054413\end{array}$ & $\begin{array}{l}0.6474 \\
0.4947 \\
0.9806 \\
0.0309 \\
0.4521 \\
0.8199 \\
0.9621 \\
0.0485\end{array}$ \\
\hline & R-squared & 0.626020 & \\
\hline & Adjusted R-square & 0.588080 & \\
\hline & Mean dependent $\mathrm{v}$ & 40.95078 & \\
\hline & Durbin-Watson stat & 1.726438 & \\
\hline
\end{tabular}

\section{Conclusion}

The current study about value relevance of accounting information and its impact on stock prices is based on financial market of Pakistan. The data is collected for commercial banks of Pakistan registered with State Bank of Pakistan. Twenty banks for the period from 2007-2012 were selected for analysis about value relevance of accounting information in the banking sector of Pakistan. We used panel data for analysis which present some benefits over the time series data and also includes that the individuals, firms, and countries are intergeneous. It has also the advantages of high and more variability and high degree of freedom and also reduces the co linearity between variables.

This table shows the descriptive statistics of the variables used in the study. The total observations for the descriptive statistics are 113 Data reveals some useful information. It

was found that the mean value of average market price of the share among the sample firm is 34.5 rupees with the maximum value of 399 rupees. The average operational profit of the firm is 4283.676 . Average EQUITY was found to be 27604.367, this means that among the group of selected firms the average value of equity is 27604.367 . Descriptive statistics also revealed that the sample firms had an average of 3.63 rupees per share of earning. Firm size (FS) has an average value of 2.473 this means that $\log$ of total assets of the sample firms is 2.473 .

The correlation analysis is also performed and we found the Correlation of ASP with OP is 0.60 which means that there is a strong positive correlation between variables which means that when ASP increases the value of OP also increases by 60 percent. However, Correlation matrix shows that there is a weak correlation between ASP and Equity (0.173). The correlation between ASP and FS is positive and the strength of the relation is 0.480 . It is depicted in the correlation matrix that there is a strong positive correlation between ASP and EPS. These findings are consistent with the findings of Nayer el al (2012), in which they concluded that firm size has a positive impact on share price. Their results show that investor gives more importance to the firm size while making investment decisions. Further the above results are also consistent with the findings of Parera and Tarikawala, (2010), Mohammadi et al (2012), and Abu Mutair (2012), in which the Firm Size, Earning per Share and Operational Profit were Value Relevant and had an impact on Investors Decisions. The Age of the firm is found to have a positive correlation with average Share Price.

The regression analysis shows that equity is not significant with dependent variable i.e. Average stock price and also have negative coefficient value $(-0.425)$ which shows negative effect of equity on Average stock price. The reason is that financial service firms differ from non financial firms on debt and equity basis. In financial service firms debt (deposits) is considered as raw material, which can be sold at higher price. Financial service firms traditionally tend to use more debt in funding their business in order to have more predictable earnings and because of regulatory frame work (Damodaran, 2009), so we reject our H1 hypothesis. Operational profit is significant and has a positive effect (7.101). Operational profit is significant 0.003 and has a positive effect on ASP. operational profit gives the idea of general health of a company. If company is facing higher operating income then it is making more money for share holders leading towards upward movement in share prices. Elliott and Hanna (1995) showed that investors attach more value to Operational profit. The EPS is significance (0.000) and have positive effect (8.92) on stock price. Earnings per share strongly affect the average stock price. This accepts our H3, firm size $\log (\mathrm{FS})$ is significance (0.05) with the average share price and has a positive effect (1.72) on the ASP. Its shows that firm size has an effect on the share price of the firm. In 2LSL analysis $\mathrm{R}$ squared of the model for dependent variable (average share price) is 0.80 . The result explains that $80 \%$ variation is explained by the explanatory variables of the model and only $20 \%$ variation remains unexplained by independent variables. The results of the two-stage model are optimal. The result of GMM shows that adjusted R-squared is $62 \%$ and equity, age, operational profit and economic growth is insignificant. The finding shows that EPS, NTA and firm size are significant and shows positive relationship with dependant variable, i.e. share price. Incremental regression is done to check which variable is more contributing in the model. Earnings per share is the most significant variable in the model and also the most effective variable in the model, $38 \%$ change has been made by earning per share, which shows that it is the most important variable for the model, it means that earning per share gives the most important and valuable information to the invertors. When we replaced the EPS in the model it became normal to its original position. This study examines the value relevance of accounting information, and the findings are consistent with previous studies. The results indicates that accounting information is value relevant in Pakistani Banks and the most variables are significant expect equity, on the other hand EPS, OP, firm size are important for investors. It provide evidence to investors about accounting information, which they must consider before making investment decisions

\section{Recommendations for further studies}

The finding shows that accounting information is value relevant in Pakistani financial market. Investors rely on accounting information for their decision making. This study has several limitations which are as follows:

The first limitation is the data set used in this study is limited to banking sector, there are only 21 public limited banks working in Pakistan. This can be overcome by conducting research in other sectors and including a large sample. Second the time period is limited to six years, but financial data is available for several years which can be used for further studies for more efficient results. Further research can cover the comparative study of Pakistani market and other developed financial markets to check the impact of value relevance. This will guide us regarding adopting and implementation of accounting rules/principals for Pakistani firms. Control variables like political stability, financial market structure, financial accounting practices, IFRS adoption and use of GAAP can give a clear picture regarding value relevance. There is need to enhance awareness of investors and their conviction of the importance of using accounting information for investment. There is need to encourage investors to increase their knowledge of accounting information and its impact on the buying decisions. Companies should pay attention to publish accounting information in newspapers independently.

\section{References:}

Abiodun,B.Y., (2012), "The Significance of Accounting Information on corporate values firms in Nigeria”, Emerging Academy Resource

Aiman, E., (2012), Aiman, A.Ragal. and Mohammad, M., Oman, "Accounting Information and value Relevance and Investor Behaviour in Egyptian Equity Market.

Abumutair, A.A., Alnairab, M.K., (2012),"Role of Accounting Disclosure in guiding the investment decisions Palestine Exchange, The Islamic University-Gaza 
Anandarjan, A., Francis, A., Hassan, I., (2010), "Value Relevance of Banks global evidence, () Springer Science Business Media, LLC 2010 Acc (2011) 36:33-55.

Collins, D.W., Maydew E.L., \& Weiss I. (1997). Changes in the value relevance of earnings and book values over the past forty years. Journal of Accounting and Economics, 24, 39-6.

Chen,K.C., (2008), "Investors Sentiment and Use of Accounting Information". October,2008 University of Southern California.

Deaconu, A., Buiga.A., Nistor.S., (2010), "The Value Relevance of Fair Value: Evidence for Tangible Assets on the Romanian Market" Transit Stud Rev., Vol.17. Pp-151-169

Elisa, H., (2013), Halonen.Elisa.Pavlovic Jelana.Persson.Rickard, "Value Relevance of Accounting Information and its impact on Stock Price: Evidence fromSweden"Department of Economics, Stockholm University.

Francis, J., LaFond, R., Olsson, P. \& Schipper, K. (2004): Costs of equity and earnings attributes, Accounting Review 79(4), pp. 967-1010.

Francis, J. and K. Schipper 1999. "Have Financial Statements Lost their Relevance." Journal of Accounting Research 37 (No 2 Autumn): 319352 .

Ghayoumi,A.F., et al (2011), "Value-Relevance of Accounting Information: Evidence form Iranian Emerging Stock Exchange". World Academy of Science, Emerging and Technology 542011.

Hadi,M.M.,(2004), "The importance of accounting information on investors in Banking sector" Dapartment of accounting, College of Business administration, Kuwait University. mehdi@cba.edu.kw

Khanagha, B.J., (2011), "Value Relevance of accounting Information in the United Arab Emirates" International Journal of Economics and Financial Issues. Vol.1, No.2, 2011, pp.33-45.ISSN:2146-4138. www.econjournals.com

Mohammadi, A., (2012), "Accounting Information and Values of the companies". Euro Journals publishing INC 2012.

Nayeri,D.M., Ghayoumi,F.A., Bidari,A.M., (2012), "Factor affecting the Value Relevance of Accounting Information" International Journal of Academic Research in Accounting, Finance and Management Sciences ., Vol 2, Issue.2(2012), ISSN:2225-8392.

Ohlson, J. Earnings. (1995). Book values, and dividends in equity valuation. Contemporary Accounting Research, 661-687.

Prera, A., (2010), P.A.A.S. Perera. S.S.Thrikawala.,"An Empirical study of the Relevance of Accounting Information in Investment Decisions". ICBI 2010 University of Kelaniya Srilanka. 